\title{
Response to water deficit of Nothofagus dombeyi plants inoculated with a specific (Descolea antarctica Sing) and non-specific (Pisolithus tinctorious (Pers.) Coker \& Couch) ectomycorrhizal fungi
}

\author{
Respuesta al déficit hídrico de plantas de Nothofagus dombeyi inoculadas con un hongo \\ ectomicorrícico específico (Descolea antarctica Sing) y no específico (Pisolithus \\ tinctorious (Pers.) Coker \& Couch)
}

\begin{abstract}
MIREN ALBERDI ${ }^{1}$, MARICEL ÁLVAREZ $^{2}$, EDUARDO VALENZUELA $^{3}$, ROBERTO GODOY $^{2}$, ERICK OLIVARES ${ }^{2} \&$ MÓNICA BARRIENTOS $^{2}$
\end{abstract}

\author{
${ }^{1}$ Departamento de Ciencias Químicas, Facultad de Ingeniería, Ciencias y Administración, \\ Universidad de La Frontera, Casilla 54-D, Temuco, Chile \\ ${ }^{2}$ Instituto de Botánica, Facultad de Ciencias, Universidad Austral de Chile, \\ Casilla 567, Valdivia, Chile \\ ${ }^{3}$ Instituto de Microbiología, Facultad de Ciencias, Universidad Austral de Chile, Casilla 567, Valdivia, Chile \\ *e-mail for correspondence: malberdi@ufro.cl
}

\begin{abstract}
The influence of the specific Descolea antarctica $(D a)$ and the non-specific Pisolithus tinctorious (Pt) ectomycorrhizal fungi on some physiological leaf parameters of the Chilean evergreen Nothofagus dombeyi subjected to a low soil water potential (-1.6 to $-1.9 \mathrm{MPa}$ in a growth chamber for 35 days) and a high water potential (-0.07 to $-0.09 \mathrm{MPa}$, control) was studied. Drought decreased the water status and increased carbohydrates in mycorrhizal and non-mycorrhizal plants, appearing $D a$-mycorrhizal and non mycorrhizal plants better osmotically adjusted $(\mathrm{OA}=0.60 \mathrm{MPa}$ and $0.52 \mathrm{MPa}$, respectively) than Pt-mycorrhizal $(0.39$ $\mathrm{MPa}$ ). Proline is not involved in the $\mathrm{OA}$ of mycorrhizal plants. The inoculation of $N$. dombeyi with both ectomycorrhizal fungi favored a better maintenance of the functionality of the photosynthetic apparatus under drought as indicated by the effective quantum yield (ФPSII). It is concluded that both ectomycorrhizal and non-mycorrhizal $N$. dombeyi plants responded to water deficit with OA adjustment, having $D a$-mycorrhizal plants a greater OA than Pt-mycorrhizal plants.
\end{abstract}

Key words: Nothofagus dombeyi, ectomycorrhizal fungi, water deficit, osmotic adjustment, photochemical performance of the PSII.

\section{RESUMEN}

Se estudió la influencia de la micorrización con un hongo ectomicorrícico específico Descolea antarctica (Da) y uno no específico Pisolithus tinctorious (Pt), de la siempreverde arbórea Nothofagus dombeyi, sobre algunos parámetros fisiológicos foliares, en plántulas sometidas a déficit hídrico (potencial hídrico del suelo entre -1,6 a -1,9 MPa) y en plantas bien irrigadas (potencial hídrico del suelo entre $-0,07$ a $-0,09 \mathrm{MPa}$ ), por 35 días en una cámara de crecimiento. La sequía disminuyó el estado hídrico e incrementó los carbohidratos de las plantas micorrizadas y no micorrizadas. Plantas micorrizadas con $D a$ y no micorrizadas presentaron un mejor ajuste osmótico $(\mathrm{AO}=0,60$ y $\mathrm{MPa})$ y $0,52 \mathrm{MPa}$, respectivamente) que las micorrizadas con $P t(0,39$ $\mathrm{MPa}$ ). Prolina no estuvo involucrada en el AO de las plantas micorrizadas. La inoculación de $N$. dombeyi con los dos hongos ectomicorrícicos favoreció una mejor mantención de la funcionalidad del aparato fotosintético ante el déficit hídrico, como lo demostró el rendimiento cuántico efectivo (ФPSII). Se concluye que tanto las plantas ectomicorrizadas como las no micorrizadas responden al déficit hídrico con ajuste osmótico, siendo este mayor en las plantas micorrizadas con $D a$ que en las micorrizadas con Pt.

Palabras clave: Nothofagus dombeyi, hongo ectomicorrícico, déficit hídrico, ajuste osmótico, desempeño fotoquímico del PSII. 


\section{INTRODUCTION}

Water deficit is one of the most important abiotic factors that limit plant growth and yield in many areas around the world. Water deficit of plants can be alleviated by mycorrhizal associations due to a variety of morphophysiological and biochemical strategies (Bréda et al. 2006). Mycorrhizal fungi alter the root system morphology, enabling infected plants to explore more soil volume and extract more water than nonmycorrhizal plants during drought (Davies et al. 1996). This provides to mycorrhizal plants subjected to drought with adequate water uptake and internal hydration to preserve their physiological activity more efficiently than non-mycorrhizal plants (Nelsen 1987, Bryla \& Duniway 1997, Morte et al. 2000, Augé 2001). An increase in compatible solutes, such as total soluble carbohydrates and proline in the cells may also help to mycorrhizal plants in the maintenance of an adequate physiologic activity under water stress with respect to the controls (Augé et al. 1986, Augé 2001, Porcel \& Ruiz-Lozano 2004). This accumulation of solutes is often involved in the osmotic adjustment (OA) of cells of mycorrhizal plants, a process by which water potential can be decreased without an accompanying decrease in turgor (Augé 2001). Usually, mycorrhizal symbiosis increases the drought resistance of host plants throughout the above mentioned mechanisms (Augé 2001).

Many studies have shown that the decrease of photosynthesis under water stress can be associated with perturbations of the photochemical processes (Lauer \& Boyer 1992, Yordanov et al. 2003). In particular, photosystem II (PSII) is very sensitive to water stress, because it results in damage of the electron transport system linked to PSII (He et al. 1995). It is reported that, the photochemical efficiency of PSII of some mycorrhizal plants subjected to water deficit was better that those of non-mycorrhizal plants under the same conditions (Sánchez-Blanco et al. 2004).

The most abundant literature about the effects described above is referred to the arbuscular mycorrhizal (AM) symbiosis (Augé 2001). Moreover, many studies have approached this theme on ectomycorrhizal woody plants (Parke et al. 1983, Davies et al.
1987, Osonubi et al. 1991, Morte et al. 2000, Shi et al. 2002, Swaty et al. 2003). The results of these studies revealed that under drought stress, mycorrhizal plants generally have a better water balance than non-micorrhizal ones. No information about this topic exists for mycorrhizal Chilean trees.

Nothofagus dombeyi (Mirb.) Oerst (Fagaceae) is a frequent evergreen species from the temperate forest of South Central Chile and Argentina (Donoso et al. 2004). It occupies a broader range of habitats, including sites with annual precipitation usually $<1500$ $\mathrm{mm}$ and several weeks of summer drought (Veblen et al. 1996). N. dombeyi is also a pioneer tree in unfavorable habitats subjected to high irradiance, extreme temperatures, drought and episodic atmospheric saturation deficits, especially in summer (Weinberger 1973). This species has been proposed for the regeneration of the degraded native forest in south central Chile, because of its rapid growth (Veblen et al. 1996). Nevertheless, nothing is known about the physiological changes that occur as a response to the interaction between ectomycorrhizal fungi and this species under water deficit (Palfner 2001). These associations are obviously of interest to those seeking drought-resistant species/plants that can be used for the reforestation program and soil preservation of areas where water availability may be restricted.

In Chile, fungi associations of $N$. dombeyi roots with Descolea antarctica (Singer), which is an autochthonous ectomycorrhizae from the temperate forest of South America, are very common and it is evolutive well adapted to the chilean habitats (Palfner 2001). However, the ecophysiologic host plant responses to environmental conditions are unknown. Pisolithus tinctorious (Pers.) Coker $\&$ Couch is a cosmopolitan ectomycorrhizal fungi which are not associated with $N$. dombeyi, but is a very studied fungi species, and exist a considerable amount of literature related with the host plant responses to several environmental conditions. Both ectomycorrhizal fungi are different morphologic characteristics, being the mycorrhizae of D. antarctica small, monopodial and loosely ramified and rhizomorphs lacking (Palfner 2001) in comparison with $P$. tinctorious which has a 
more ramified and developed mycorrhiza (Carney 1992). In reforestation programs is reported that $P$. tinctorious is an early colonizer and it is regarding as been poorly competitive with other ectomycorrizae fungi (Chambers \& Carney 1999). In attention to the described characteristics of both mycorrhizal types, we found of great interest to explain the physiological response to water deficit of $N$. dombeyi mycorrhized with these fungus strains.

The aim of this work was to study the variations in physiological parameters (leaf water status, compatible solutes, pigments and photochemical performance of the PSII) in $N$. dombeyi seedlings inoculated with a specific autochthonous ectomycorrhizal fungus Descolea antarctica and the non-specific (cosmopolitan) ectomycorrhizal fungus Pisolithus tinctorius under water deficit and their recovery capacity after rehydration. It is expected, that the non-mycorrhizal plants will be more affected under low water conditions than inoculated mycorrhizal plants. Additionally, we expect that the mycorrhization of $N$. dombeyi plants with the native fungus (good adapted for the root colonization of this species) may be more effective to provide a better physiologic behavior of the host plant than the mycorrhization with the cosmopolitan fungi strain.

\section{MATERIAL AND METHODS}

\section{Experimental design}

The experimental design was a randomized complete block with a $3 \times 3$ factorial treatment with three inoculate (with $D$. antarctica, $P$. tinctorius, and without), three irrigation treatments (WW, DR, and rehydration or recovery) and five replicates each.

\section{Plant material and experimental conditions}

One year old $N$. dombeyi seedlings proceeding from seeds from a humid-temperate forest located in Valdivia in south central Chile $\left(40^{\circ}\right.$ $S)$ were used in this study. Seeds were proved in their viability by a floatability test, and the viable seeds were subjected to a humid stratification in sand in a refrigerator at $4{ }^{\circ} \mathrm{C}$ for three months. Thereafter the seeds were translated to Petri-dish provided with wet filter and incubated to $20{ }^{\circ} \mathrm{C}$ in a growth chamber until the primary root attained $1 \mathrm{~mm}$ long. Then, they were transplanted, in pots filled with the same soil type mentioned below, and maintained in a greenhouse for 1 year. At this time seedlings from similar characteristics (biomass and structure) were transplanted to plastic pots $(18.5 \mathrm{~cm}$ depth $\mathrm{x}$ $13 \mathrm{~cm}$ diameter) filled with $13.5 \mathrm{~cm}$ of autoclaved $\left(120{ }^{\circ} \mathrm{C}\right.$ for $\left.50 \mathrm{~min}\right)$ organic soil (ground pine substrate). These seedlings were grown in a growth chamber at $25 / 20{ }^{\circ} \mathrm{C}$ (day/ night), $60-80 \%$ air relative humidity (RH), and a photosynthetic photon flux density (PPFD) of $100 \mu \mathrm{mol} \mathrm{m} \mathrm{m}^{-2} \mathrm{~s}^{-1}$ at the top of the canopy, provided by cool-white fluorescent tubes F40CW (General E, Charlotte, NC, USA), during 30 days. They were watered twice a week alternatively with water and nutrient solution. After this time, seedlings were inoculated with ectomycorrhizal $P$. tinctorius (isolate 441, provided by the Institute of Environmental Science and Technology, University of Bremen, Germany) and with ectomycorrhizal inocula of $D$. antarctica obtained from fruiting bodies collected in the temperate forest of $N$. dombeyi, in the Puyehue National Park, Chile $\left(41^{\circ} \mathrm{S}, 72^{\circ} \mathrm{W}\right.$ at $725 \mathrm{~m}$ of altitude). The fungi were grown on solid Melin-Norkrans culture media (MNM) (Alvarez et al. 2005) in the dark at $\mathrm{pH} 5$ and $25^{\circ} \mathrm{C}$, for one month. Mycorrhizal inocula were prepared in $1 \mathrm{dm}^{3}$ autoclaved culture bottles $\left(120{ }^{\circ} \mathrm{C}\right.$ for $20 \mathrm{~min}$ at $1 \mathrm{~atm})$, containing a mixture of $65 \mathrm{~g}$ of vermiculite and $300 \mathrm{~mL}$ of $\mathrm{MNM}$ at $\mathrm{pH}$. The plugs have been isolated from the leading edge of 1 month old stock cultures with a sterile cork borer ( $7 \mathrm{~mm}$ diameter). After four weeks, plugs showing actively growing hyphae were used for inoculation according to Alvarez et al. (2005). Four weeks after inoculation, main and lateral short roots were infected, as demonstrated anatomically by the formation of a paraepidermal Hartig net and a plectenchymatous mantle. Inoculated and non inoculated seedlings were maintained in the growth chamber for one month at the same conditions mentioned above, before the application of the water treatments in the laboratory. 


\section{Water treatment}

Seedlings inoculated with $P$. tinctoruis (IN-Pt) and with $D$. antarctica (IN-Da) and non inoculated (non-IN), were subjected to normal irrigation (well watered, WW) and to a drought treatment (droughted, DR). Soil moisture was measured as volumetric water content $(\mathrm{VWC}=$ water vol/soil vol x 100) using a Time Domain Reflectometry (TDR, IMKO) soil moisture meter (Trimelog, Ettlingen, Germany). Soil volume was $2 \mathrm{~L}$. The value for one pot was the average of three measurements made at a depth of $18 \mathrm{~cm}$ (the length of the guides of the TDR' probes) at three equidistant points. Values of volumetric water content $\left(\theta_{\mathrm{v}}\right)$ of soil were transformed in water potential $\left(\Psi_{\text {soil }}\right)$ values by comparison of $\left(\theta_{\mathrm{v}}\right)$ with the corresponding $\Psi_{\text {soil }}$ of the same soil obtained by PF-curves. Data were obtained from Fernández (2006). In the WW treatment, soils were maintained at $\theta_{\mathrm{v}} 8.5$ $19.5 \%\left(\Psi_{\text {soil }}-0.07\right.$ to $\left.-0.09 \mathrm{MPa}\right)$ while in the DR treatment, soils were maintained at $\theta_{\mathrm{v}}$ 2.6$3 \%\left(\Psi_{\text {soil }}-1.6\right.$ to $\left.-1.9 \mathrm{MPa}\right)$. Plants were maintained in a growth chamber at $25 / 20{ }^{\circ} \mathrm{C}$ (day/night), 50-60\% air relative humidity, and a PPFD of around $100 \mu \mathrm{mol} \mathrm{m} \mathrm{m}^{-2} \mathrm{~s}^{-1}$ at the top of the canopy, provided by cool-white fluorescent tubes F40CW (General E, Charlotte, NC, USA), during 35 days, until determinations were made. This time was selected, because it exceeds the usual number of summer days without rains in the habitats of this species. To avoid physiological diurnal changes, determinations and leaf samples collections were made at around 12:00 and 14:00 h. After the drought period, plants were rehydrated to the same $\theta_{\mathrm{v}}$ of soil of the WW plants for three weeks and then subjected to the same plant analyses as plants from the other treatments. The experimental period up the plants were inoculated was 116 days (60 of inoculation and 35 days of water stress and 21 days of recovery).

\section{Plant water status measurements}

As indicators of the water status of plants relative water content (RWC), water potential $\left(\Psi_{\mathrm{w}}\right)$ and osmotic potential $\left(\Psi_{\pi}\right)$ of leaves were determined. Relative water content (RWC) was determined as $\mathrm{RWC}=(\mathrm{FW}-\mathrm{DW}) /(\mathrm{SW}-\mathrm{DW}) \mathrm{x}$ 100. Fresh weight (FW) was determined shortly after the leaves were excised from the plants. Saturated weight (SW) was determined after rehydration for 12 hours in dark and the dry weight (DW) was determined after oven drying at $70{ }^{\circ} \mathrm{C}$ for at least $48 \mathrm{~h}$. Leaf water potential $\left(\Psi_{\mathrm{w}}\right)$ was determined in $8 \mathrm{~cm}$-long plant apices with around 6 leaves, using a pressure chamber (Model 1000 PMS Instrument Company, Albany, USA) according Sholander et al. (1965). For determination of the leaf osmotic potential $\left(\Psi_{\pi}\right)$, leaves were harvested and subjected to hydration by dipping their petioles in distilled water, allowing them to reach full turgor overnight, and then freezing them in liquid nitrogen. After thawing, the $\Psi_{\pi}$ of expressed sap was measured psychrometrically with a L-51 chamber coupled to a HR-33T psychrometer microvoltmeter (Wescor Inc., Logan, UT) (Malone \& Tomos 1992). This method can result in an over-estimation of the $\Psi_{\pi}$ due to dilution of symplastic water by apoplastic water, but it is better to establish differences among treatments (Edwards \& Dixon 1995). The osmotic adjustment (OA) was estimated as the difference in $\Psi_{\pi}$ at full turgor between the well watered and low watered treatment (Lemcoff et al. 1994).

\section{Determination of "in vivo" chlorophyll a fluo- rescence parameters}

For evaluation of the functionality of the photosynthetic apparatus of the host plant under water deficit, the photochemical efficiency of PSII was evaluated by the emission of chlorophyll fluorescence signals, which were measured by a pulse-amplitude modulated fluorometer (FMS 1, Hansatech Instruments Ltd., Norfolk, United Kingdom). The fluorometer was connected to a leaf-clip holder with an optic fiber and to a computer with data acquisition software (FMS 1.05). The experimental protocol of Genty et al. (1989) was basically followed. The leaf disc was continuously illuminated with white actinic light at an intensity of around $100 \mu \mathrm{mol} \mathrm{m} \mathrm{m}^{-2} \mathrm{~s}^{-1}$ which was equivalent to growth PPDF of $N$. dombeyi plants in the growth chamber. The steady-state value of fluorescence (Fs) was thereafter recorded and a saturating pulse at $8,000 \mu \mathrm{mol} \mathrm{m} \mathrm{m}^{-2} \mathrm{~s}^{-1}$ was imposing to determine the maximal fluorescence level in light-adapted leaves (Fm'). The actinic light was removed 
and the minimal fluorescence level in the light adapted state (Fo') was determined by illuminating the leaf disc with applying a $2 \mathrm{sec}$ far red light pulse. As indicators of the integrity of the photosynthetic apparatus and therefore of the overall photosynthesis, the effective quantum yield of the PSII (ФPSII), and the photochemical quenching (qP) were used (van Kooten \& Snel 1990). ФPSII was calculated as (Fm' - Fs)/Fm' (Genty et al. 1989), and qP as $($ Fm' - Fs $) /($ Fm' - Fo'). Since fluorescence parameters $(\mathrm{Fv} / \mathrm{Fm}=$ variable fluorescence $)$ obtained in the dark remained in the range of healthy leaves $(\mathrm{Fv} / \mathrm{Fm} \cong 0.8$, Krause \& Weis 1991), no values are given in the results .

\section{Pigments analysis}

Chlorophylls and total carotenoids were determined in foliar tissue of the host plants. Leaves were placed in a cold mortar with a minimal amount of $\mathrm{MgCO}_{3}$ and ground with 80 $\%(\mathrm{v} / \mathrm{v})$ cold acetone: water at $4{ }^{\circ} \mathrm{C}$ under $\operatorname{dim}$ light. Extinction of pigments extracts was measured in a spectrophotometer (Metertek SP 850 , Taipei, Taiwán) at 663, 646 and $470 \mathrm{~nm}$. Pigments concentrations were calculated according to Lichtenthaler \& Welburn (1983).

\section{Compatible solutes determinations}

Carbohydrates were extracted from fresh leaf tissue in $86 \% \mathrm{v} / \mathrm{v}$ ethanol with overnight agitation. The samples were depigmented in a $3: 1 \mathrm{v} / \mathrm{v}$ chloroform: water mixture. The aqueous fraction was lyophilized overnight and the carbohydrates resuspended in $500 \mu \mathrm{L}$ of methanol. Total soluble carbohydrate (TSC) content was determined spectrophotometrically by the resorcinol method (Roe 1934) by measuring $\mathrm{A}_{520}$, using sucrose as standard. Additionally, the root TSC were determined by the same procedure mentioned for leaves for orientation of the carbohydrate partition in the host plants.

Free proline was determined colorimetrically according to Bates et al. (1973). Leaves were ground in liquid nitrogen and extracted with 5 $\mathrm{mL}$ of $3 \%$ sulphosalicylic acid. After filtration through Whatman $\mathrm{N}^{\circ} 1$ filter paper, $2.5 \mathrm{~mL}$ of extract were used for the acid ninhydrin reaction. Ninhydrin-proline complexes were extracted in toluene and the $\mathrm{A}_{546}$ was compared with a standard curve obtained with pure proline (Merck KGaA, Darmstadt, Germany).

\section{Statistics}

Two-way analyses of variance (ANOVA) were used to test the effects and interactions of ectomycorrhizal fungi ( $P$. tinctorius and $D$. antarctica) and water treatments on water status parameters, chlorophyll $a$ fluorescence, pigments and metabolites. Sigma Stat 2.0 software (SPSS ${ }^{\circledR}$ Inc., Chicago, Illinois, USA) was used for the statistic analyses and a Bonferrony test was used to identify those values with significant differences $(\mathrm{P} \leq 0.05)$. Interactions will be discussed only if they are statistically significant.

\section{RESULTS}

\section{Water status parameters}

RWC of leaves of IN-Pt and non-IN plants as well $\Psi_{\mathrm{w}}$ and $\Psi_{\pi}$ of leaves of both IN and nonIN seedlings decreased significantly $(\mathrm{P} \leq 0.05)$ under DR conditions with respect the WW seedlings (Fig. 1A, 1B and 1C). All the plants attained their initial water status parameters after recovery with exception of non-inoculated seedlings, where a lower $\Psi_{\pi}$ was found (Fig. $1 \mathrm{~A}, 1 \mathrm{~B}$ and $1 \mathrm{C})$. The $\mathrm{OA}$ of leaves in drought stressed plants were largest in IN-Da $(0.60 \pm$ $0.07 \mathrm{MPa})$ and non-IN $(0.52 \pm 0.01 \mathrm{MPa})$ plants than in IN-Pt $(0.39 \pm 0.02 \mathrm{MPa})(\mathrm{P} \leq$ $0.05)$ ones. There are not a statistically significant interaction between the water regime levels and inoculation. $\mathrm{P} \geq 0.134$ for CRA, $\Psi_{\omega}$ and $\Psi_{\pi}$.

\section{Compatible solutes}

TSC were higher in leaves than in roots (Fig. $2 \mathrm{~A}$ and $2 \mathrm{~B}$ ). No differences between non-IN and IN seedlings were found in leaf TSC in the WW treatment. At the DR treatment a greater accumulation of leaf TSC than in WW seedlings occurred in both IN and non-IN plants, being the percentages of accumulation in IN-Pt lower (46\%) than those of IN-Da (104 $\%)$ and non-IN $(84 \%)(\mathrm{P} \leq 0.05)$. Both mycorrhizal plants showed lower TSC than non-NI ones by rehydration after drought, 


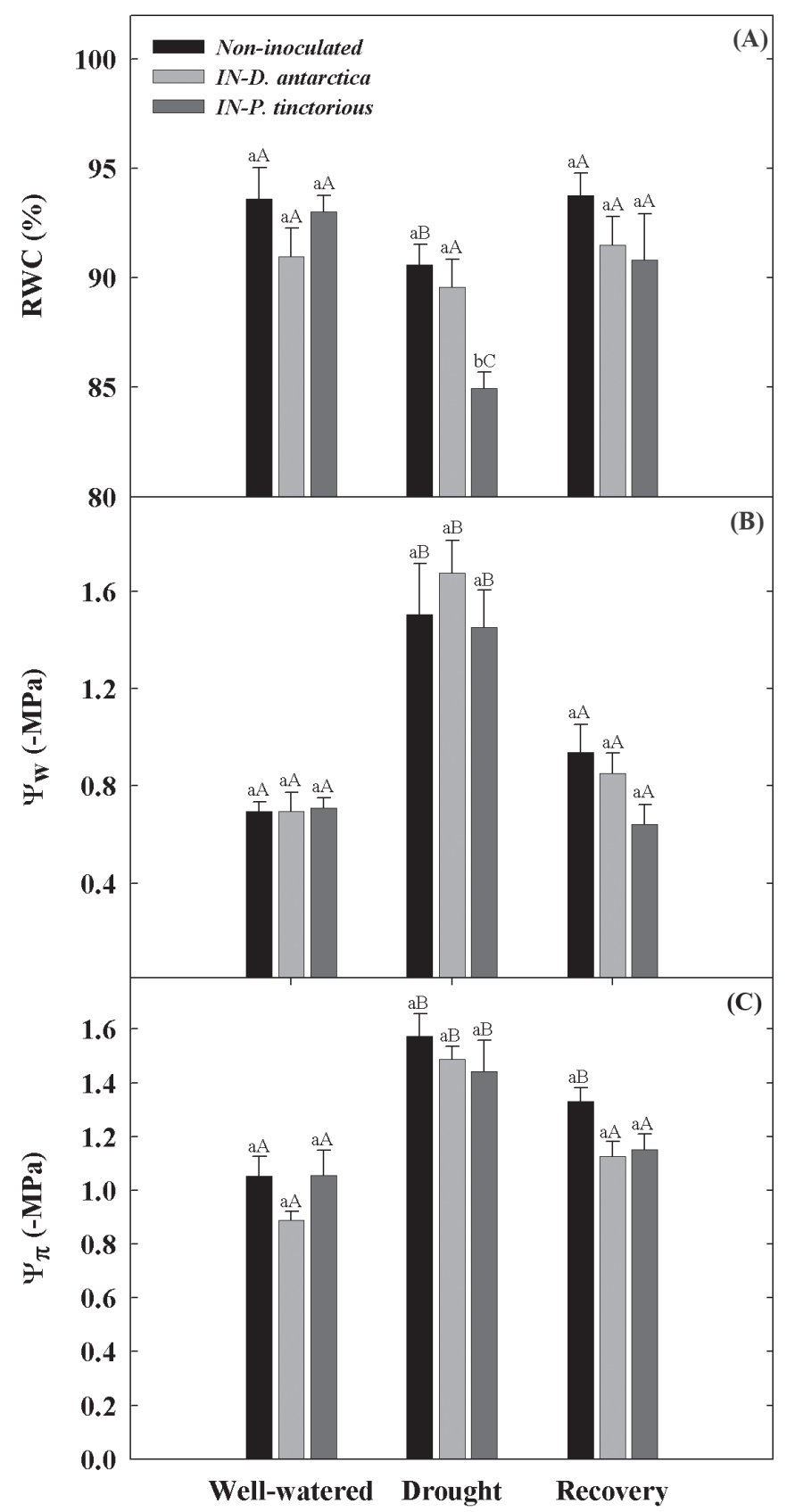

Fig 1: Effect of D. antarctica and P. tinctorious ectomycorrhizal fungi on water leaves parameters of $N$. dombeyi seedlings subjected to water stress and recovery. (A) Relative water content (RWC), (B) water potential $\left(\Psi_{\mathrm{w}}\right)$, and $(\mathrm{C})$ osmotic potential $\left(\Psi_{\pi}\right)$. Each point represents the mean of five replicates $\pm \mathrm{SE}$ for each treatment. Different lower case letters indicate statistically significant differences $(\mathrm{P} \leq 0.05)$ for the non-inoculated (NI) and inoculated (IN) treatments at a determinate irrigation level. Different upper case letters show statistically significant differences $(\mathrm{P} \leq 0.05)$ for the NI and IN treatments at different irrigation levels. For interactions, see the text.

Efecto de los hongos ectomicorrícicos D. antarctica and $P$. tinctorious sobre los parámetros hídricos foliares de plántulas de $N$. dombeyi sometidas a estrés hídrico y recuperación. (A) Contenido relativo de agua (RWC), (B) potencial hídrico $\left(\Psi_{\mathrm{w}}\right)$, y $(\mathrm{C})$ potencial osmótico $\left(\Psi_{\pi}\right)$. Cada punto representa el promedio de cinco réplicas \pm EE para cada tratamiento. Letras minúsculas diferentes indican diferencias estadísticamente significativas $(\mathrm{P} \leq 0,05)$ para los tratamientos sin inoculación (NI) y con inoculación (IN) a un determinado nivel de irrigación. Letras mayúsculas diferentes indican diferencias estadísticamente significativas $(\mathrm{P} \leq 0,05)$ para los tratamientos sin inoculación (NI) y con inoculación (IN) a un determinado nivel de irrigación. Las interacciones se encuentran descritas en el texto. 


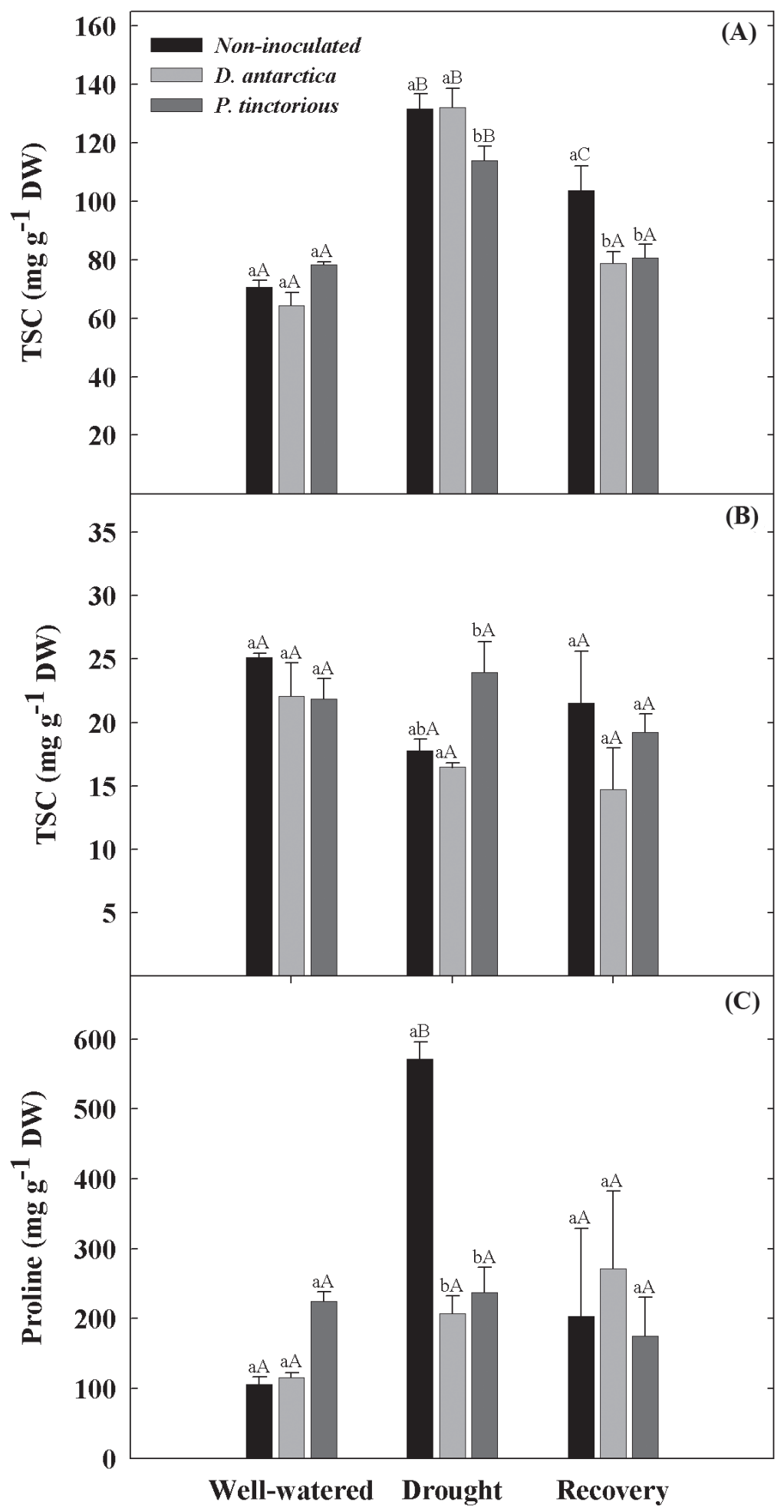

Fig. 2: Effect of D. antarctica and P. tinctorious ectomycorrhizal fungi on compatible solutes of $N$. dombeyi seedlings subjected to water stress and recovery. Total soluble carbohydrates (TSC) in (A) leaves, (B) roots, and (C) proline content in leaves (c). All other aspects as in Fig. 1.

Efecto de los hongos ectomicorrícicos D. antarctica and $P$. tinctorious sobre los solutos compatibles de plántulas de $N$. dombeyi sometidas a estrés hídrico y recuperación. Carbohidratos solubles totales (TSC) en (A) hojas, (B) en raíces, y (C) contenido de prolina en las hojas. Todos los otros aspectos como en Fig. 1. 
attaining similar TSC than WW. Roots TSC had no differences $(P \geq 0.05)$ between the irrigation treatments, but they accumulated $34 \%$ more in IN-Pt plants than in IN-Da and non-IN ones (Fig. 2B). No accumulation of proline under DR with respect to WW plants was found in leaves of IN plants (Fig. 2C). However, non-IN seedlings accumulated more as two fold proline than IN under this condition $(\mathrm{P} \leq 0.05)$. Upon recovery, plants of all irrigation treatments attained similar values than WW plants. There is a statistically significant interaction between water regime levels and inoculation for TSC of leaves $(\mathrm{P}=$ $0.005)$ and proline $(\mathrm{P}<0.001)$.

\section{Chlorophyll a fluorescence parameters}

ФPSII, and $\mathrm{qP}$ did not show differences between IN and non-IN plants in the WW treatment and after recovery (Fig. 3A and 3B). Under DR conditions, $\Phi$ PSII of both IN-Da and IN-Pt, were higher $(\mathrm{P} \leq 0.05)$ than NI plants and WW plants, attaining by recovery similar values than WW plants (Fig. 3A). The qP was very stable in all treatments, with exception of IN-Da plants which showed a higher qP when subjected to DR conditions or after recovery ( $\mathrm{P}$ $\leq 0.05)$. There is statistically significant interaction between the irrigation treatments (WW and DR) and the mycorrhizal fungi inoculation for $\Phi$ PSII $(\mathrm{P} \leq 0.05)$.

\section{Pigment contents}

In WW plants Chl $a$ and $\mathrm{Chl} b$ contents of IN-Pt mycorrhizal plants were higher and carotenoids lower than in non-IN and IN-Da plants ( $\mathrm{P} \leq$ 0.05) (Fig. 4A, 4B and 4C). Under DR conditions no differences in the Chl $a$ and $\mathrm{Chl} b$ contents were found between the IN and non-IN plants. At this water level, IN-Da plants increased and IN-Pt decreased their contents in Chl $a$ and Chl $b$ with respect to the WW plants (P $\leq 0.05$ ), whereas in non-IN plants these contents remained constant. Similar values as in the DR treatment were obtained in the recuperation treatment for both IN and non-IN plants. However, recuperated IN-Pt plants did not attained the initial values of well irrigated plants $(\mathrm{P} \leq 0.05)$. In the WW treatment carotenoids of IN-Pt plants were significantly lower than plants of the other treatments. No differences in the carotenoid concentrations of IN and non-IN plants were found between $\mathrm{WW}$ and DR plants (Fig. 4C). Upon recovery, IN-Pt plants attained carotenoid concentrations similar to WW plants, while non-IN and IN-Da plants did not reached the concentrations of normal irrigated plants $(\mathrm{P}$ $\leq 0.05)$. For pigments there was a significant interaction between water regime levels and inoculation $(\mathrm{P} \leq 0.025)$.

\section{DISCUSSION}

Our study showed that the water status parameters decreased significantly under DR conditions in all treatments, with exception of the RWC of IN-Da plants, in mycorrhizal and non-mycorrhizal $N$. dombeyi plants. This decrease was associated with a leaf TSC accumulation with respect to the WW plants. These results agree only partially with other reports, where a greater carbohydrate leaf accumulation under drought is found in arbuscular-mycorrhizal (AM) plants but not in non mycorrhizal plants (Subramanian \& Charest 1995, Subramanian et al. 1997, Augé 2001). Accumulation of carbohydrates, which suggests maintenance of greater photosynthetic capacity has been attributed to a greater drought resistance in mycorrhizal maize plants (Subramanian \& Charest 1995, Subramanian et al. 1997). These plants showed a less stressinduced accumulation of amino acids than non mycorrhizal plants and were able to sustain a more normal nitrogen metabolism. In our experiment, the mycorrhizal plants subjected to water deficit, showed also a lower proline accumulation than non-mycorrhized plants. There are also contrary evidences with respect to carbohydrates accumulation by drought in AM plants of tobacco, rose and pepper, which accumulated less soluble carbohydrates in their tissues than non-mycorrhizal ones (Augé et al. 1987, Schellenbaum et al. 1998, Augé 2001). These opposite results suggest that each host plant and fungus genotype has a specific behavior with respect its water balance.

Comparing the effect of the ectomycorrhizal fungus on the accumulation of TSC and OA under drought conditions in leaves of $N$. dombeyi plants with respect to those of $\mathrm{WW}$, it appears that the $D$. antarctica mycorrhization was more efficient in the accumulation of TSC 
and the OA (1.5 fold more) (Fig. 2A) of $N$. dombeyi than those with $P$. tinctorius $(\mathrm{P} \leq$ 0.05). Nevertheless, because non mycorrhizal plants showed similar TSC and OA than IN-Da plants under drought conditions we cannot assume a higher drought resistant in the IN-Da with respect to the IN-Pt plants. Then, these results suggest that, for some unknown reason, $P$. tinctorious has a negative effect on the accumulation of TSC in leaves which seems to be at expenses of an increase in roots TSC with respect to IN-Da plants as reported for tobacco plants (Schellenbaum et al. 1998).

Enhanced OA in response to drought stress is not a general strategy in mycorrhizal and non-mycorrhizal plants. Whereas an increase of $\mathrm{OA}$ is reported in mycorrhizal rose plants subjected to water stress but nor in pepper (Augé et al. 1986, Davies et al. 1993) neither in Pinus taeda (loblolly pine) seedlings colonized with the ectomycorrhizal fungi $P$. tinctorius (Davies et al. 1996).

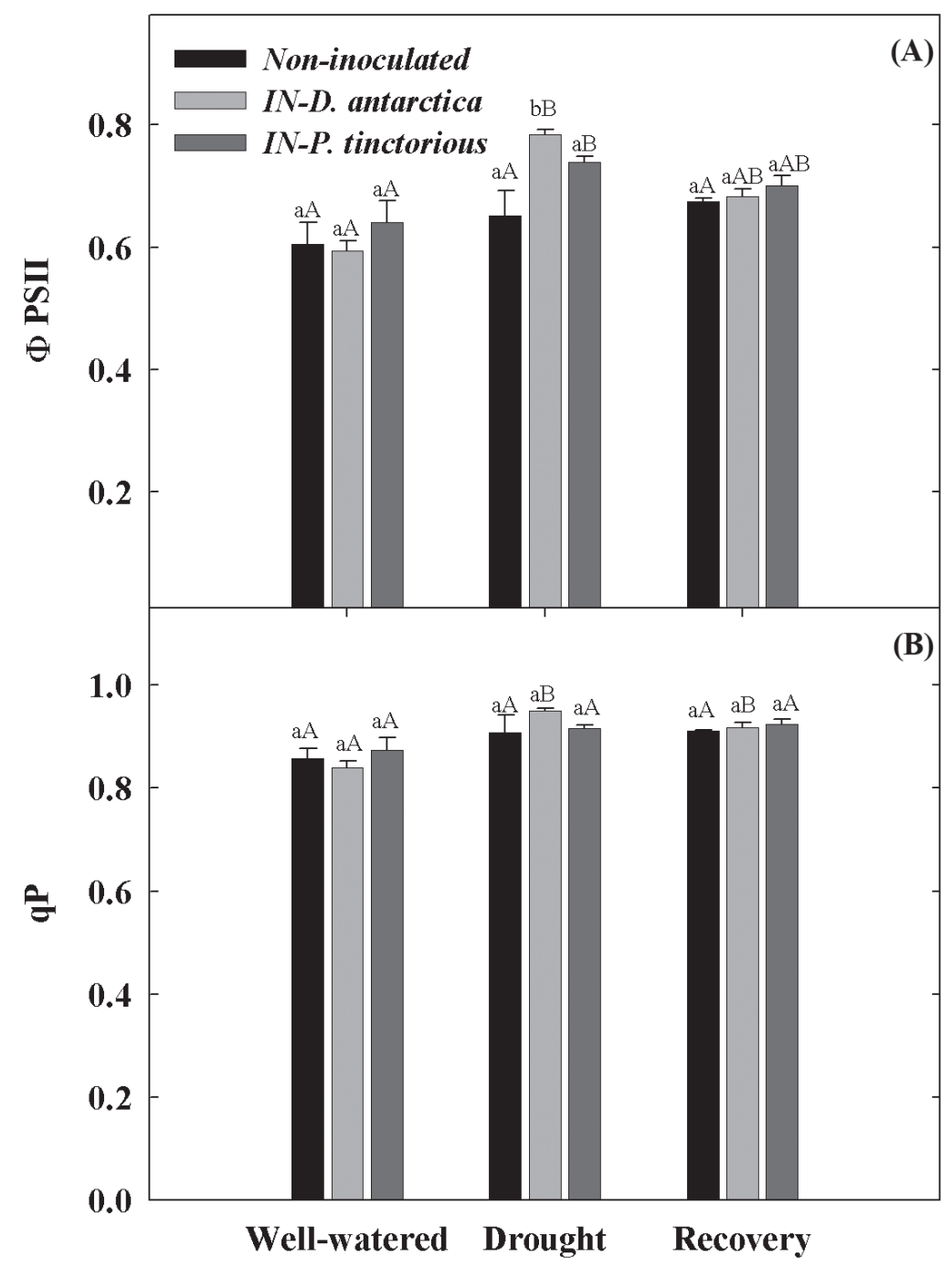

Fig. 3: (A) Effective quantum yield of the PSII (ФPSII), and (B) photochemical quenching (qP) of $N$. dombeyi seedlings mycorrhized with $D$. antarctica and $P$. tinctorious ectomycorrhizal fungi subjected to water stress and recovery. All other aspects as in Fig. 1.

(A) Rendimiento cuántico efectivo del PSII (ФPSII) y (B) apagamiento fotoquímico (qP) en plántulas de $N$. dombeyi ectomicorrizadas con $D$. antarctica and P. tinctorious y sometidas a estrés hídrico. Todos los otros aspectos como en Fig. 1. 


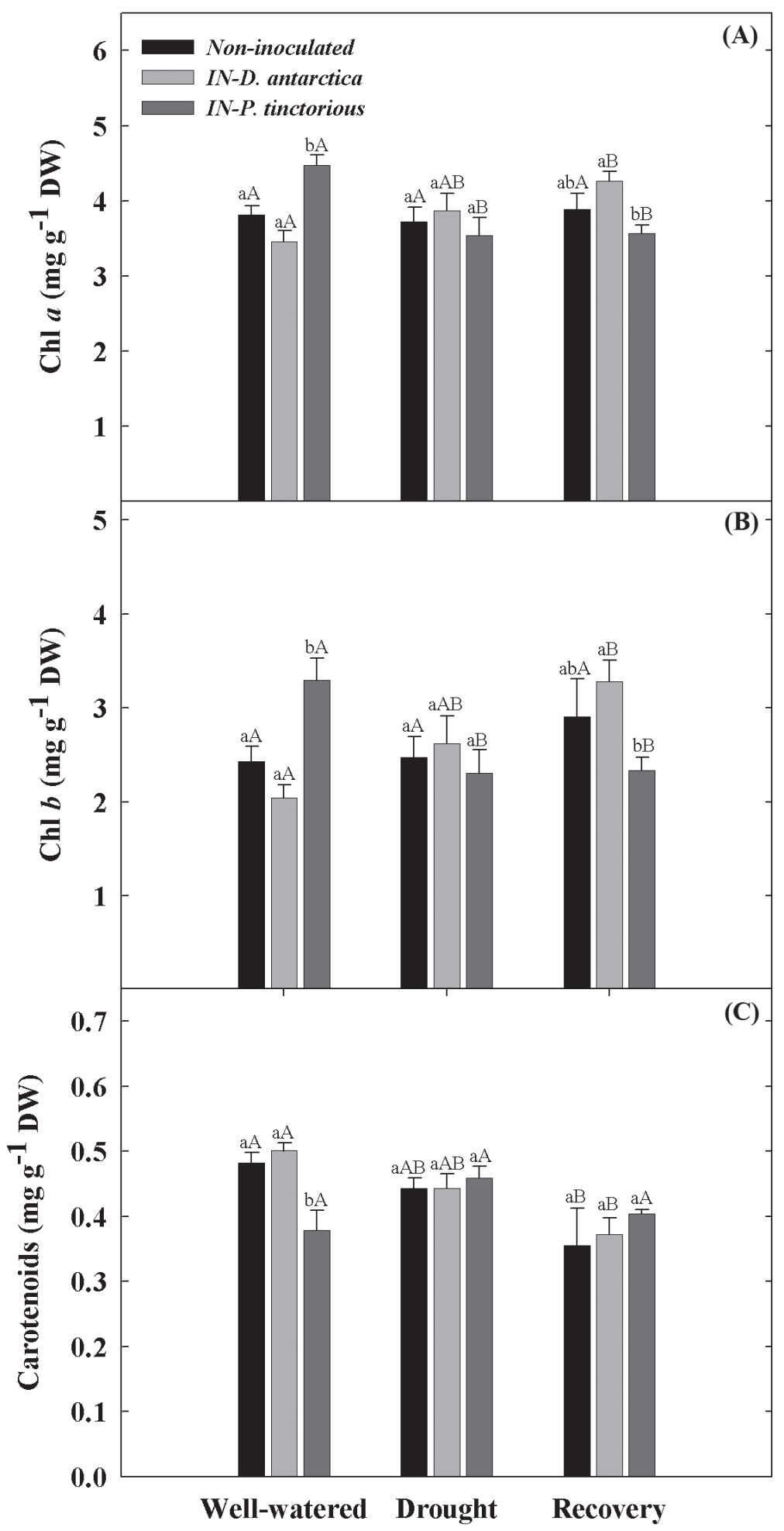

Fig. 4: Changes in leaves pigments of $N$. dombeyi seedlings mycorrhized with $D$. antarctica and $P$. tinctorious ectomycorrhizal fungi subjected to water stress and recovery. (A) Total chlorophyll (Chl $a+b)$, (B) chlorophyll $b$ and (C) carotenoids. All other aspects as in Fig. 1.

Cambios en los pigmentos foliares de plántulas de $N$. dombeyi ectomicorrizadas con $D$. antarctica and P. tinctorious y sometidas a estrés hídrico y recuperación. (A) Clorofila total (Chl $a+b)$, (B) chlorofila $b$ y (C) carotenoides. Todos los otros aspectos como en Fig. 1. 
We assume that despite the water parameters decreased under the DR treatment, in NI and IN-Pt and IN-Da seedlings, the leaf cell water hydration was adequate to maintain the functionality of the photosynthetic machinery, as evidenced by the similar or higher values of the DPSII obtained under DR conditions with respect to the WW (Fig. 3A). Nevertheless, according to this parameter the inoculation of $N$. dombeyi with both ectomycorrhizal fungi favored the maintenance of a higher functionality of the photosynthetic apparatus under DR conditions (interaction $\mathrm{P} \leq$ $0.05)$, coinciding with the findings in ectomycorrhized Rosmarinus officinalis plants subjected to water stress (Sánchez-Blanco et al. 2004). In the case of IN-Da seedlings subjected to water stress compared with those of the WW conditions also qP values, which are indicative of a better delivery of energy to photosynthesis (Maxwell \& Johnson 2000), support a better behavior of the photosynthetic performance of the photosynthetic apparatus (Fig. 3). That the functionality of the photosynthetic apparatus was not affected during drought is also shown by recovery experiments, where the indicators of the photochemical efficiency of photosystem II attained similar values than well watered plants.

Munné-Bosch \& Alegre (2000) and Sánchez-Blanco et al. (2004) reported that under water deficiti inoculated Rosmarinus officinalis plants with Glomus deserticola showed an increase in chlorophyll content associated with a higher photochemical efficiency $\Phi P S I I$ with respect the the noninoculated plants. In our experiment this was not the case, where despite higher FPSII in both mycorrhizal plants total $\mathrm{Chl}$ was maintained or decreased significantly $(\mathrm{P} \leq$ $0.05)$ in IN-Da and IN-Pt seedlings respectively, under water limitation with respect to the WW plants (Fig. 4A and 4B). Interestingly, leaves of IN-Pt plants showed the highest chlorophyll contents under WW conditions $(\mathrm{P} \leq 0.05)$. This result could be explained in a better capacity of the fungi $P$. tinctorious than $D$. antarctica to colonize the roots of the host plant. This assumption is supported by the work of Gemma et al. (1998), where the mycorrhizal colonization of roots of a well watered grass was significantly correlated, with higher chlorophyll content.
Higher chlorophyll contents of mycorrhizal plants have sometimes been associated with higher rates of photosynthesis (Mathur \& Vyas 1995).

Chlorophylls and carotenoids which can help to cope with oxidative stress induced by drought (Fryer 1992, Maslova \& Popova 1993, Munné-Bosch \& Alegre 2000), practically did not change under water deficit conditions in our work. Higher antioxidant enzyme activity were found in roots of both IN-Pt and IN-Da N. dombeyi plants subjected to the same water deficit as in our work (Fernández 2006). According to this author superoxide dismutase (SOD) and glutathione reductase (GR) activity were higher in the treatment with $P t$ and catalase and ascorbate peroxidase in the treatment with $D a$. Thus, both fungi provide to $N$. dombeyi roots with a defense again reactive species of oxygen.

Our study showed that under drought a six fold accumulation of proline was observed in NI- $N d$ with respect to WW plants $(\mathrm{P} \leq 0.05)$, which can suggest that this population could present a higher capacity of osmotic adjustment under water stress (Subramanian \& Charest 1995). Thus, in this case, proline (Fig. 2C) may participate in the OA under water deficit of non-mycorrhizal plants but not in inoculated plants. Alternatively, proline increases under water deficit conditions has been also associated with tissue injury (Hanson 1980). This interpretation seems to be not applicable in our case, because of the corresponding higher photosynthetic performance found under DR and after recovery. Thus, the accumulation or decrease of proline in plants subjected to water deficit seems to be controversial.

Relative to the recovery after the water deficit level employed in this study, both mycorrhizal and non mycorrhizal $N$. dombeyi plants showed a good recovery capacity, attaining generally similar physiological values than WW plants.

It is important to mention that the obtained results did not permit to establish if the native or the cosmopolitan fungus strain were more efficient to provide a better physiological behavior to the host plant under drought. When statistically significant interactions between the water regime and the mycorrhizal fungus were found they were equally significant for both fungus strains. 
It can be concluded, that under the conditions of this study the inoculation of $N$. dombeyi with both ectomycorrhizal fungi favored the maintenance of a higher functionality of the photosynthetic apparatus under drought conditions. Ectomycorrhizal and non-mycorrhizal $N$. dombeyi plants responded to water deficit with OA adjustment, having $D a$-mycorrhizal plants a greater OA than $P t$ mycorrhizal plants. According that it seems that $N$. dombeyi may be genotypically resistant to water deficit. These results, together the high physiological, molecular, and morphological variability of $N$. dombeyi (Donoso et al. 2004) could contribute to explain the capacity of this species to colonize harsh open habitats.

\section{ACKNOWLEDGEMENTS}

The authors thank to FONDECYT 1040913 for financial support and to Rafael Zúñiga e Isabel Saavedra for technical assistance.

\section{LITERATURE CITED}

ÁLVAREZ M, R GODOY, W HEYSER \& S HÄRTEL (2005) Anatomical-physiological determination of surface bound phosphatase activity in ectomycorrhizae of Nothofagus oblique. Soil Biology and Biochemistry 37: 125-132.

AUGÉ RM (2001) Water relations, drought and vesiculararbuscular mycorrhizal simbiosis. Mycorrhiza 11: $3-42$.

AUGÉ RM, KA SCHEKEL \& RL WAMPLE (1986) Osmotic adjustment in leaves of VA and non mycorrhizal rose plants in responses to drought stress. Plant Physiolgy 82: 765-770.

AUGÉ RM, KA SCHEKEL \& RL WAMPLE (1987) Leaf water and carbohydrate status of VA mycorrhizal rose exposed to drought stress. Plant and Soil 99: 291-302.

BATES LS, RP WALDREN \& ID TEARE (1973) Rapid determination of free proline for water stress studies. Plant and Soil 39: 205-207.

BRÉDA N, HUC R, GRANIER A \& E DREYER (2006) Temperate forest trees and stands under severe drought: a review of ecophysiological responses, adaptation processes and long term consequences. Annals of Forest Science 63: 625-644.

BRYLA DR \& JM DUNIWAY (1997) Effects of mycorrhizal infection on drought tolerance and recovery in safflower and wheat. Plant and Soil 197: 95-103.

CARNEY JW (1992) Translocation of solutes in ectomycorrhizal and saprotrophic rhizomorphs. Mycological Research 96: 135-141.

CHAMBERS S \& JW CARNEY (1999) Pisolithus. In: Carney JW \& S Chambers (eds) Ectomycorrhizal fungi- Key genera in profile: 1-31 Springer Verlag, Berlin, Germany.
DAVIES FT, Y CASTRO-JIMÉNEZ \& SA DURAY (1987) Mycorrhizae, soil amendments, water relations and growth of Rosa multiflora under reduced irrigation regimes Scientia Horticulturae 33: 261-267.

DAVIES FT, JR POTTER \& LJ LINDERMANN (1993) Drought resistance of mycorrhizal pepper plants independent of leaf P-concentration - Response in gas-exchange and water relations. Physiologia Plantarum 87: 45-53.

DAVIES FT, SE SVENSON, JC COLE, L PHAVAPHUTANON, SA DURRAY, V OLALDEPORTUGAL, CE MEIER \& SH BO (1996) Nonnutritional stress acclimation of mycorrhizal woody plants exposed to drought. Tree Physiology 16: 985-993

DONOSO C, A PREMOLI \& P DONOSO (2004) Variación en Nothofagus siempreverdes sudamericanos. In: Donoso C, A Premoli, L Gallo \& R Ipinza (eds) Variación intraespecífica en las especies arbóreas de los bosques templados de Chile y Argentina: 189-212. Editorial Universitaria, Santiago, Chile.

EDWARDS DR, \& MA DIXON (1995) Mechanisms of drought response in Thuja occidentalis L.I. Water stress conditioning and osmotic adjustment. Tree Physiology 15: 121-127.

FERNÁNDEZ CG (2006) Cuantificación de los sistemas antioxidantes en raíces de Nothofagus dombeyi (MIRB.) OERST. micorrizadas bajo condiciones de estrés hídrico. Tesis de Licenciatura, Facultad de Ciencias, Universidad Austral de Chile, Valdivia, Chile. 114 pp

FRYER MJ (1992) The antioxidant effects of thylakoid vitamin E (a-tocopherol). Plant, Cell and Environment 15: 381-392.

GEMMA JN, RE KOSKE, EM ROBERTS, \& S HESTER (1998) Response of Taxus x media var. densiformis inoculation with arbuscular mycorrhizal fungi. Canadian Journal Forest Research 28: 150-153.

GENTY B, JM BRIANTAIS \& NR BAKER (1989) The relationship between the quantum yield of photosynthetic electron transport and quenching of chlorophyll fluorescence. Biochimica et Biophysica Acta 990: 87-92.

HANSON AD (1980) Interpreting the metabolic responses of plants to water stress. Horticultural Sciences 15: 623-629.

HE JX, J WANG \& HG LIANG (1995) Effects of water stress on photochemical function and protein metabolism of photosystem II in wheat leaves. Physiologia Plantarum 93: 771-777.

KRAUSE GH \& E WEIS (1991) Chlorophyll fluorescence and photosynthesis: the basics. Annual Review of Plant Physiology and Plant Molecular Biology 42: 313-49.

LAUER MJ \& JS BOYER (1992) Internal $\mathrm{CO}_{2}$ measures directly in leaves: abscisic acid and low water potential cause opposing effects. Plant Physiology 98: 1010-1016.

LEMCOFF JH, AB GUARNASCHELLI, AM GARAU, ME BASCIALLI \& CM GHERSA (1994) Osmotic adjustment and its use as a selection criterion in Eucalyptus seedlings. Canadian Journal of Forest Research 24: 2404-2408.

LICHTENTHALER H \& AR WELLBURN (1983) Determinations of total carotenoids and chlorophyll $a$ and $b$ of leaf extracts in different solvents. Biochemical Society Transactions 603: 591-592.

MALONE M \& AD TOMOS (1992) Measurement of 
gradients of water potentials in elongating pea stem by pressure probe and picolitre osmometry. Journal of Experimental Botany 43: 1325-1331.

MASLOVA TG \& IA POPOVA (1993) Adaptive properties of the plants pigment systems. Photosynthetica 29: 195-203.

MATHUR N \& A VYAS (1995) Influence of VA mycorrhizae on net photosynthesis and transpiration of Ziziphus mauritiana. Journal of plant Physiology 147: $328: 330$

MAXWELL K \& GN JOHNSON (2000) Chlorophyll fluorescence-a practical guide. Journal of Experimental Botany 51: 659-668.

MORTE A, C LOVISOLO \& A SCHUBERT (2000) Effect of drought stress on growth and water relations of the mycorrhizal association Helianthemum almeriense - Terfezia claveryi. Mycorrhiza 10: 115119.

MUNNÉ-BOSCH S, L ALEGRE (2000) Changes in carotenoids, tocopherols and diterpenes during drought and recovery, and the biological significance of chlorophyll loss in Rosmarinus officinalis plants. Planta 210: 925-931.

NELSEN CE (1987) The water relations of vesiculararbuscular mycorrhizal systems. In: Safir GR (ed) Ecophysiology of VA mycorrhizal plants: 71-91. CRC Press, Boca Raton, Florida, USA.

OSONUBI O, K MULONGOY, OO AWOTOYE, MO ATAYESE \& DUU OKALI (1991) Effects of ectomycorrhizal and vesicular-arbuscular mycorrhizal fungi on drought tolerance of four leguminous woody seedlings. Plant and Soil 136:131-143

PARKE JL, RG LINDERMAB \& CH BLACK (1983) The role of ectomycorrhizas in drought tolerance of Douglas fir seedlings. New Phytologie 95: 83-95.

PALFNER G (2001) Taxonomische studien an ektomykorrhizen aus den Nothofagus-Wäldern Mittelsüdcheles. Bibliotheca Mycologica 190: 243 pp.

PORCEL R \& JM RUIZ-LOZANO (2004) Arbuscular mycorrhizal influence on leaf water potential, solute accumulation, and oxidative stress in soybean plants subjected to drought stress. Journal of Experimental Botany 55: 1743-1750.

ROE JH (1934) A colorimetric method for the determination of fructose in blood and urine. Journal of Biological Chemistry 107: 15-22.

SÁNCHEZ-BLANCO MJ, T FERRÁNDEZ, MA MORALES, A MORTE \& JJ ALARCÓN (2004)
Variations in water status, gas exchange, and growth in Rosmarinus officinalis plants infected with Glomus deserticola under drought conditions. Journal of Plant Physiology 161: 675-682.

SCHELLENBAUM L, J MÜLLER, T BOLLER, A WIEMKEN \& H SCHÜEPP (1998) Effects of drought on non-mycorrizal and mycorrhizal maize: changes in the pools of non-structural carbohydrates, in the activities of invertase and trehalase, and in the pools of amino acids and imino acids. New Phytologist 138: 59-66.

SCHOLANDER PF, HT HAMMEL, EA HEMMIGSEN \& ED BRADSTREET (1965) Sap pressure in vascular plants. Science 48: 339-346.

SHI L, M GUTTENBERGER, I KOTTKE \& R HAMPP (2002) The effect of drought on mycorrhizas of beech (Fagus sylvatica L.): changes in community structure, and the content of carbohydrates and nitrogen storage bodies of the fungi. Mycorrhiza 12: 303-311

SUBRAMANIAN KS \& C CHAREST (1995) Influence of arbuscular mycorrhizae on the metabolism of maize under drought stress. Mycorrhiza 5: 273-278

SUBRAMANIAN KS, C CHAREST, LM DWYER \& RI HAMILTON (1997) Effects of arbuscular Mycorrhizae on leaf water potential, sugar content, and $\mathrm{P}$ content during drought and recovery of maize. Canadian Journal of Botany 75: 1582-1591.

SWATY RL, RJ DECKERT, WHITHMAM T \& GEHRING CA (2003) Ectomycorrhizal abundance and community composition shifts with drought: predictions from tree rings. Ecology 85: 1072-1084.

VAN KOOTEN O \& JFH SNEL (1990) The use of chlorophyll fluorescence nomenclature in plant stress physiology. Photosynthesis Research 25: 147150 .

VEBLEN TT, C DONOSO, T KITSBERGER \& AJ REBERTUS (1996) Ecology of southern Chilean and Argentinean Nothofagus forests. In: Veblen TT, RS Hill \& J Read (eds) The ecology and biogeography of Nothofagus forests: 293-353. Yale University Press, New Haven, Connecticut, USA.

WEINBERGER P (1973) Beziehungen zwischen mikroklimatische Faktoren und natürlicher Verjüngung araukano-patagonischer NothofagusArten. Flora 162: 157-179.

YORDANOV I, V VELIKOVA \& T TSONEV (2003) Plant responses to drought and stress tolerance. Bulgarian Journal of Plant Physiology, Special Issue: $187-206$. 
